\title{
Ekmeklik buğday (Triticum aestivum $L$.) genotiplerinin verim ve verim unsurları ile glutenin ve gliadin bant desenlerinin belirlenmesi*
}

\author{
Determination of yield, yield components, glutenin and gliadin patterns of bread \\ wheat (Triticum aestivum L.) genotypes
}

\author{
Bekir AKTAŞ ${ }^{1}$, Saime Ünver İKİNCİKARAKAYA ${ }^{2}$ (i) \\ ${ }^{1}$ Tohumluk Tescil ve Sertifikasyon Merkez Müdürlüğü, Yenimahalle/Ankara \\ ${ }^{2}$ Ankara Üniversitesi Ziraat Fakültesi Tarla Bitkileri Bölümü Dışkapı/Ankara \\ Sorumlu yazar (Corresponding author): B. Aktaş, e-posta (e-mail): bekir_aktas@yahoo.com \\ Yazar(lar) e-posta (Author e-mail): sunver@agri.ankara.edu.tr
}

MAKALE BİLGİSİ

Alınıș tarihi 15 Ağustos 2018

Düzeltilme tarihi 04 Ocak 2019

Kabul tarihi 07 Ocak 2019

Anahtar Kelimeler:

Ekmeklik buğday

Verim

Verim unsurları

Glutenin

Gliadin

\begin{abstract}
$\ddot{\mathbf{o z}}$
$\mathrm{Bu}$ çalıșma; Ankara Üniversitesi Ziraat Fakültesi Haymana Araștırma ve Uygulama Çiftliği'nde 2007-2008 ve 2008-2009 yetiştirme dönemlerinde yürütülmüştür. Tesadüf blokları deneme desenine göre 4 tekrarlamalı olarak 17 ekmeklik buğday çeşidi ile yürütülen bu araștırmada; çeșitlerin verim ve verime etkili bazı unsurların farklı iki yılda değișimlerinin belirlenmesi amaçlanmıştır. İklim koşulları açısından araştırmanın yürütüldüğü iki yetiştirme dönemi, uzun yıllar ortalamasına göre oldukça farklılık göstermiștir. İncelenen tüm özellikler bakımından yıllar arasında farklılık önemli bulunmuş bu nedenle yıllar birleştirilmeden ayrı ayrı değerlendirilmiștir. İncelenen tüm özellikler yönünden çeşitler arasındaki farklılıklar da önemli bulunmuş ve çeșitler gruplandırılmıştır. En düşük ve en yüksek değerlere göre sırasıyla birinci ve ikinci yıl; metrekarede fertil başak sayısı 253.8-385.0 ve 306.3-532.5 adet, başakta fertil başakçık sayısı 13.85-20.03 ve 15.60-20.20 adet, başakta tane sayı1s $22.58-43.75$ ve 26.18-50.43 adet, başakta tane verimi $0.818-1.626$ ve $1.090-2.253 \mathrm{~g}$, birim alan tane verimi $127.5-192.2$ ve $219.2-420.2 \mathrm{~kg} \mathrm{da}^{-1}$, bin tane ağırlığ $28.08-34.12$ ve 33.36-45.23 $\mathrm{g}$ arasında değișim göstermiştir. Glu-A1 lokusunda; 11 çeșit $2^{*}, 4$ çeșit 1 bandına sahip olup, 2 çeşitte ise bant bulunmamıştır. Glu-B1 lokusunda; 10 çeşit $7+8,3$ çeşit $7+9,3$ çeşit $17+18$ bantları ve 1 çeşit ise 7 bandı taşımaktadır. Glu-D1 lokusunda; 11 çeşit 5+10, 6 çeșit ise $2+12$ bantlarına sahiptir.
\end{abstract}

\section{ARTICLE INFO}

Received 15 August 2018

Received in revised form 04 January 2019

Accepted 07 January 2019

\section{Keywords:}

Bread wheat

Yield

Yield components

Glutenin

Gliadin

\begin{abstract}
This study was carried out at the Ankara University, Faculty of Agriculture, Haymana Research and Application Farm during 2007-2008 and 2008-2009 growing seasons. In this research, the aim of this study was to determine the variation of yield and some of the yield components that affect yield on different varieties in two years. The experiments were conducted with four replications in randomized complete block design with 17 bread wheat varieties. In terms of climate conditions, the two growing cycles in which the study was conducted were considerably different compared to average of long years. The results obtained for the analyzed parameters per year were significantly different; therefore, the years were separately evaluated. The differences among the varieties in relation to all characteristics taken into account were found out to be important so the varieties were grouped. According to minimum and maximum values of the varieties for the first year and second year respectively, fertile spike number per square meter ranged from 253.8 to 385.0 and it varied from 306.3 532.5, number of fertile spikelets per spike 13.85-20.03 and 15.60-20.20, number of grain per spike 22.58-43.75 and 26.18-50.43, grain weight per spike 0.818-1.626 g and 1.090-2.253 g, grain yield 127.5-192.2 $\mathrm{kg} \mathrm{da}^{-1}$ and $219.2-420.2 \mathrm{~kg} \mathrm{da}^{-1}$, 1000 kernel weight 28.08-34.12 $\mathrm{g}$ and $33.36-45.23 \mathrm{~g}$. Band $2 *$ (in 11 varieties), band 1 (in 4 varieties) and no band (in 2 varieties) on Glu-A1 locus have been determined. Bands $7+8$ (in 10 varieties), bands $7+9$ (in 3 varieties), bands $17+18$ (in 3 varieties) and band 7 (in one variety) on Glu-B1 locus have been determined. Bands $5+10$ (in 11 varieties), bands $2+12$ (in 6 varieties) on Glu-D1 locus have been determined.
\end{abstract}




\section{Giriş}

Ülkemizde insan beslenmesinde önemli bir yere sahip olan buğday, adaptasyon yeteneğinin yüksek olması nedeniyle büyük ekiliş alanına ve yüksek bir üretim değerine sahiptir. Gıdanın öneminin her geçen gün arttığı dünyada buğdaya olan ihtiyaç, gelecekte de artarak devam edecektir (Kün 1988). Ülkemizin tarımsal alanının büyük bir bölümünün ekolojik şartlarının buğday tarımını zorunlu kılması yanında makinalı tarıma uygunluğu, ürünün muhafazası, pazarlaması ve taşınmasının kolay olması gibi etkenler de buğday tarımının yaygınlığını arttırmaktadır (Akkaya 1994).

Küresel 1sınma sonucunda dünyada olduğu gibi ülkemizde de uzun yıllar ortalamalarından büyük sapmalar yaşanmaktadır. Bunun sonucunda tarımsal üretimde düşüşler yaşanmaktadır. 2007-2008 ekim yılında kuraklık ve sıcaklıkların yüksek seyretmesi buğday üretiminde düşüşe neden olmuştur. Bir sonraki ekim yılında ise ekilen alan hemen hemen aynı iken üretim miktarı yaklaşık 3 milyon ton artış göstermiştir (TÜİK 2017). Üretimdeki artışa karşılık un ve makarna sanayicisi açısından kalite sorunu ortaya çıkmıştır. Türkiye'de buğday tarımı yapılan alanların önemli bir kısmını sulama yapılmayan kuru tarım alanları oluşturmaktadır (Aydoğan ve Soylu 2017). Kontrol edilemeyen ekolojik koşullar, 1slahçıları değişken çevre şartlarına uyum yeteneği yüksek genotipleri elde etmeye yönlendirmektedir.

Türkiye'nin farklı ekolojilere sahip olması nedeniyle uzun y1llar süren bitki ıslah çalışmaları ile elde edilen yeni çeşitlerin kayıt altına alınmasında bölgesel denemeler yapılmaktadır. Bölgesel denemeler yanında kuru ve sulu koşullar da ayrı ayrı değerlendirilmektedir. Orta Anadolu Bölgesinin sahip olduğu iklim koşullarından dolayı temel tarımsal ürünü buğday ve arpadir. Uzun yillar boyunca Bezostaja 1 ve Gerek 79, Orta Anadolu Bölgesi kuru tarım alanlarında en fazla ekilişe sahip çeşitler olmuştur. 2008 y1lında; Bezostaja 1 çeşidi 35556 ton, Gerek 79 ise 5831 ton sertifikalı tohumluk üretimine sahiptir (TTSMM 2009). 2016 yılına gelindiğinde; Bezostaja 1 çeşidi 17768 ton, Sönmez 200112938 ton, Tosunbey 9252 ton, Bayraktar 20007944 ton sertifikalı tohumluk üretimine sahiptir
(TTSMM 2016). Gerek 79 çeşidinin ise yok denecek kadar az sertifikalı tohumluk üretimi bulunmaktadır.

Yurtdışından ülkemize getirilen çeşitlerin büyük bölümü Avrupa ülkelerinde 1slah edilmiş çeşitlerdir. Bu çeşitlerin tescil başvuruları, ağırlıklı olarak yıllık yağış miktarı fazla veya sulu tarım yapılan bölgeler için yapılmaktadır. Özellikle Orta Anadolu Bölgesi kuru koşullar için yurtdışı kökenli çeşit başvurusu yok denecek kadar azdır. Bu çalışmada; Orta Anadolu Bölgesi için tescil edilmiş çeşitlerin aynı çevre koşullarında verim ve verim üzerine etkili unsurların belirlenmesi ile biyokimyasal desenlerinin ortaya konması amaçlanmıştır.

\section{Materyal ve Yöntem}

Bu çalışmada; Bezostaja 1, Köse 220/39, Kıraç 66, Gerek 79, Gün 91, Kırgız 95, İkizce 96, Aytın 98, Harmankaya 99, Karahan 99, Altay 2000, Demir 2000, Bayraktar 2000, Sönmez 2001, Tosunbey, Seval ve Müfitbey ekmeklik buğday çeşitleri materyal olarak kullanılmıştır. Bezostaja 1; Rusya'da 1slah edilmiş, ülkemizde 1968 yılında kayıt altına alınmıştır. Diğer 16 çeşit ise sırasıyla Tarla Bitkileri Merkez Araştırma Enstitüsü Müdürlüğü, Geçit Kuşağı Tarımsal Araştırma Enstitüsü Müdürlüğü ve Bahri Dağdaş Uluslararası Tarımsal Araştırma Enstitüsü Müdürlügü tarafından kuru koşullar için farklı yıllarda 1slah edilmiştir.

Deneme alanı İç Anadolu Bölgesinin karasal iklim yapısına sahip olup, ortalama aylık ve uzun yıllar sıcaklık, yağış ve oransal nem değerleri Çizelge 1'de verilmiştir (MGM 2009). Bu veriler incelendiğinde, iki yetiştirme döneminde yağış miktarı ve dağılımı ile sıcaklık bakımından uzun yıllar ortalamasından sapmalar göstermiştir. İlk deneme yılında yıllık toplam yağıŞ miktarı $309.0 \mathrm{~mm}$, ikinci yetiştirme döneminde ise büyük bir artış göstererek $502.1 \mathrm{~mm}$ olarak gerçekleşmiştir. Deneme alanı; kahverengi toprak grubunda olup, kireç oranı yüksektir. Organik madde miktarı ve fosfor az, potasyum yeterli seviyededir. Her iki yetiştirme döneminde denemeler birbirine yakın nadas yapılan parsellerde kurulmuştur.

Çizelge 1. Deneme yerine ait iklim verileri (MGM 2009).

Table 1. Climatic data of experimental area (MGM 2009).

\begin{tabular}{lccccccccc}
\hline \multirow{2}{*}{ Aylar } & \multicolumn{3}{c}{ Yağıș $(\mathbf{m m})$} & \multicolumn{3}{c}{ Sıcaklık $\left({ }^{\mathbf{O}} \mathbf{C}\right)$} & \multicolumn{3}{c}{ Nispi Nem $(\%)$} \\
\cline { 2 - 8 } Eylül & $\mathbf{2 0 0 7 - 0 8}$ & $\mathbf{2 0 0 8 - 0 9}$ & U.Y. Ort. & $\mathbf{2 0 0 7 - 0 8}$ & $\mathbf{2 0 0 8 - 0 9}$ & U.Y. Ort. & $\mathbf{2 0 0 7 - 0 8}$ & $\mathbf{2 0 0 8 - 0 9}$ & U.Y. Ort. \\
Ekim & 0 & 38.3 & 17.1 & 17.9 & 17.4 & 17.0 & 41.0 & 58.6 & 53.1 \\
Kasım & 16.1 & 17.9 & 22.3 & 12.3 & 10.6 & 11.6 & 56.0 & 74.7 & 65.4 \\
Aralık & 79.1 & 39.3 & 30.8 & 5.4 & 6.2 & 5.1 & 78.0 & 82.7 & 73.1 \\
Ocak & 46.5 & 33.0 & 40.7 & -4.8 & -0.9 & 0.4 & 82.0 & 93.1 & 79.4 \\
Subat & 17.0 & 48.2 & 34.8 & -5.7 & 0 & -1.7 & 87.7 & 89.1 & 78.3 \\
Mart & 16.0 & 69.0 & 32.6 & -2.4 & 1.8 & -0.3 & 78.9 & 87.6 & 76.4 \\
Nisan & 52.2 & 65.7 & 36.4 & 7.9 & 2.9 & 4.1 & 64.5 & 81.2 & 73.1 \\
Mayıs & 24.6 & 59.4 & 39.6 & 11.5 & 8.6 & 9.4 & 61.9 & 73.9 & 65.4 \\
Haziran & 41.6 & 41.7 & 45.5 & 12.8 & 13.1 & 13.8 & 59.9 & 69.3 & 63.3 \\
Temmuz & 15.9 & 43.3 & 30.9 & 19.4 & 18.9 & 18.1 & 47.9 & 56.2 & 57.5 \\
Ağustos & 0 & 24.5 & 15.0 & 22.1 & 21.1 & 21.6 & 41.5 & 54.8 & 49.8 \\
\hline Toplam & 0 & 21.8 & 12.7 & 23.7 & 22.7 & 21.6 & 40.0 & 89.1 & 48.6 \\
\hline Ortalama & 309.0 & 502.1 & 358.4 & - & - & - & - & - & - \\
\hline
\end{tabular}


Denemeler; Ankara Üniversitesi Ziraat Fakültesi Haymana Araştırma ve Uygulama Çiftliği'nde 2 yetiştirme dönemi (20072008 ve 2008-2009) boyunca tesadüf blokları deneme desenine göre 4 tekrarlı olarak yürütülmüştür. Çeşitler; $20 \mathrm{~cm}$ sira aralığında, altı sıralı parsel ekim makinası kullanılarak $6 \mathrm{~m}^{2}$ alana sahip parsellere $(5 \times 1.2 \mathrm{~m})$ ekilmiştir. Metrekareye 500 adet canlı tohum düşecek şekilde, her çeşit için tohumluk miktarı hesaplanmıştır. Ekimde $2.3 \mathrm{~kg} \mathrm{da}^{-1} \mathrm{~N}$ ve $6.0 \mathrm{~kg} \mathrm{da}^{-1}$ $\mathrm{P}_{2} \mathrm{O}_{5}$ hesabıyla DAP gübresi verilmiştir. Sapa kalkma öncesinde $3.7 \mathrm{~kg} \mathrm{da}^{-1} \mathrm{~N}$ hesabıyla \% 33'lük amonyum nitrat verilmiştir.

$\mathrm{Bu}$ çalışmada incelenen özelliklere ait verilerin elde edilmesinde, Tosun ve Yurtman (1973), Geçit (1982) ve Ünver (1995) tarafindan ortaya konan yöntemlerden faydalanılmıştır. Veriler SAS (SAS Institute 1998) programı ile tesadüf blokları deneme desenine göre varyans analizine alınmıştır. İstatistiksel önemlilik seviyelerinin belirlenmesinde $F$ testinden yararlanılmış iken ortalamaların farklılık gruplandırmalarında ise Duncan testi kullanılmıştır.

Çeşitlerin biyokimyasal yönden tanımlanmasında yüksek molekül ağırlıklı glutenin bant desenlerinin belirlenmesi için SDS-PAGE yöntemi kullanılmıştır (UPOV 2017). Düşük molekül ağırlıklı gliadin bant desenlerinin belirlenmesinde ise Khan ve ark. (1990)'ın önerdiği yöntem uygulanmıştır.

Gliadin bantlarının değerlendirilmesinde, bantların nispi hareketliliği $(\mathrm{Rm})$ ve nispi yoğunluğu (Ri) esas alınmıştır. Nispi yoğunlukta; en az boyanan bantlara 1, en koyu boyanan bantlara ise 5 değeri verilmiştir (Bushuk ve Zillman 1978). Bantların nispi hareketliliği;

$$
\mathrm{Rm}=\frac{\text { İncelenen bandın orijinden uzaklığ }}{\text { Referans bandın orijinden uzaklığ } 1} \times 50
$$

formülüne göre hesaplanmıştır. Referans çeşit olarak Neepawa çeşidi kullanılmıştır. Neepawa'nın da R50 bandı nispi hareketliliğin ölçümünde referans alınmıştır. Araştırmada kullanılan çeşitlerin gliadin bantlarında, referans alınan banda kadar okuma yapılmıştır. Referans bandın altındaki daha düşük molekül ağırlığındaki bantlarda ise okuma yapılmamıştır.

\section{Bulgular ve Tartışma}

Yılların birleşik varyans analizinde, incelenen tüm özelliklerde yıllar arası farklılıklar istatistiksel açıdan önemli bulunmuş ve bu nedenle yıllar ayrı ayrı değerlendirilmiştir. İncelenen özelliklerin $\mathrm{F}$ değerleri, ortalama değerler, Duncan farklılık gruplandırmaları ve varyasyon katsayıları sırasıyla Çizelge 2 ve Çizelge 3'te verilmiştir.

\subsection{Metrekarede fertil başak sayısı}

Metrekarede fertil başak sayısı bakımından 2007-2008 yetiştirme döneminde 385.0 başak m$^{-2}$ ile Bayraktar 2000 çeşidi ilk sırada yer almıştır. Demir 2000 çeşidi 253.8 başak m$^{-2}$ ile en düşük metrekarede başak sayısını göstermiştir. 2008-2009 yetiştirme döneminde de Bayraktar 2000 çeşidi 532.5 başak m ${ }^{-2}$ ile en yüksek metrekarede başak sayısını verirken, 306.3 başak $\mathrm{m}^{-2}$ ile Bezostaja 1 çeşidi son sırada yer almıştır. Her iki deneme y1lında da Altay 2000, Bezostaja 1 ve Demir 2000 çeşitleri en düşük metrekarede başak sayısını gösteren çeşitler olmuştur. İkinci deneme yılında yıllık toplam yağışta ilk yıla göre 193.1 mm'lik bir yükseliş yaşanmış ve tüm çeşitlerin metrekarede fertil başak sayısında artış gözlemlenmiştir. Ancak çeşitler, metrekarede fertil başak sayısındaki oransal artış yönünden büyük farklılıklar göstermiştir. Çevre koşullarındaki iyileşmeye karşın çeşitlerin kardeşlenme potansiyellerinin birbirinden farklı oranda artış göstermesi genetik yapının da oldukça önemli olduğunu doğrulamaktadır.

Çizelge 2. Ekmeklik buğday çeşitlerinde metrekarde fertil başak sayısı, başakta fertil başakçık sayısı, başakta tane sayısına ait ortalamaların farklılık gruplandırmaları ve bazı istatistiksel değerleri.

Table 2. The grouping according to mean difference and some statistical values of fertile spike number per square meter, number of fertile spikelets per spike and number of grain per spike on the bread wheat varieties.

\begin{tabular}{lllllll}
\hline \multirow{2}{*}{ Çeşitler } & \multicolumn{2}{c}{ Metrekarede Fertil Başak Sayısı } & \multicolumn{2}{c}{ Başakta Fertil Başakçı Sayısı } & \multicolumn{2}{c}{ Başakta Tane Sayısı } \\
\cline { 2 - 7 } & $\mathbf{2 0 0 8}$ & $\mathbf{2 0 0 9}$ & $\mathbf{2 0 0 8}$ & $\mathbf{2 0 0 9}$ & $\mathbf{2 0 0 8}$ & $\mathbf{2 0 0 9}$ \\
\hline Köse 220/39 & $320.0 \mathrm{a}-\mathrm{e}$ & $437.5 \mathrm{bcd}$ & $14.03 \mathrm{jj}$ & $16.43 \mathrm{e}$ & $22.58 \mathrm{~g}$ & $26.18 \mathrm{~h}$ \\
Bezostaja 1 & $260.0 \mathrm{de}$ & $306.3 \mathrm{~g}$ & $17.33 \mathrm{c}$ & $18.78 \mathrm{~b}$ & $38.00 \mathrm{bcd}$ & $40.73 \mathrm{e}$ \\
Kıraç 66 & $307.5 \mathrm{a}-\mathrm{e}$ & $437.5 \mathrm{bcd}$ & $15.00 \mathrm{f}-1$ & $18.95 \mathrm{~b}$ & $27.10 \mathrm{f}$ & $35.48 \mathrm{~g}$ \\
Gerek 79 & $325.0 \mathrm{a}-\mathrm{e}$ & $450.0 \mathrm{bc}$ & $15.35 \mathrm{~d}-\mathrm{g}$ & $16.58 \mathrm{e}$ & $31.98 \mathrm{e}$ & $37.05 \mathrm{fg}$ \\
Gün 91 & $293.8 \mathrm{~b}-\mathrm{e}$ & $426.3 \mathrm{bcd}$ & $19.00 \mathrm{~b}$ & $20.20 \mathrm{a}$ & $38.88 \mathrm{bc}$ & $43.73 \mathrm{~cd}$ \\
Kırgız 95 & $381.8 \mathrm{a}$ & $388.8 \mathrm{cde}$ & $14.93 \mathrm{gh} 1$ & $16.85 \mathrm{de}$ & $32.40 \mathrm{e}$ & $39.38 \mathrm{ef}$ \\
İkizce 96 & $336.3 \mathrm{a}-\mathrm{d}$ & $462.5 \mathrm{~b}$ & $16.00 \mathrm{def}$ & $17.20 \mathrm{~cd}$ & $34.00 \mathrm{de}$ & $40.55 \mathrm{e}$ \\
Aytın 98 & $330.0 \mathrm{a}-\mathrm{e}$ & $408.8 \mathrm{~b}-\mathrm{e}$ & $13.85 \mathrm{j}$ & $15.60 \mathrm{f}$ & $27.38 \mathrm{f}$ & $37.38 \mathrm{fg}$ \\
Harmankaya 99 & $306.3 \mathrm{a}-\mathrm{e}$ & $416.3 \mathrm{~b}-\mathrm{e}$ & $18.80 \mathrm{~b}$ & $18.75 \mathrm{~b}$ & $42.25 \mathrm{ab}$ & $50.43 \mathrm{a}$ \\
Karahan 99 & $303.8 \mathrm{a}-\mathrm{e}$ & $446.3 \mathrm{bc}$ & $15.65 \mathrm{~d}-\mathrm{g}$ & $17.68 \mathrm{c}$ & $31.65 \mathrm{e}$ & $36.48 \mathrm{~g}$ \\
Altay 2000 & $283.3 \mathrm{cde}$ & $351.3 \mathrm{efg}$ & $16.20 \mathrm{de}$ & $18.78 \mathrm{~b}$ & $33.63 \mathrm{de}$ & $45.78 \mathrm{bcd}$ \\
Demir 2000 & $253.8 \mathrm{e}$ & $313.8 \mathrm{fg}$ & $20.03 \mathrm{a}$ & $19.95 \mathrm{a}$ & $43.75 \mathrm{a}$ & $47.33 \mathrm{~b}$ \\
Bayraktar 2000 & $385.0 \mathrm{a}$ & $532.5 \mathrm{a}$ & $14.28 \mathrm{hij}$ & $15.80 \mathrm{f}$ & $32.00 \mathrm{e}$ & $37.23 \mathrm{fg}$ \\
Sönmez 2001 & $360.0 \mathrm{abc}$ & $423.8 \mathrm{bcd}$ & $16.33 \mathrm{~d}$ & $17.30 \mathrm{~cd}$ & $38.70 \mathrm{bc}$ & $43.35 \mathrm{~d}$ \\
Tosunbey & $307.5 \mathrm{a}-\mathrm{e}$ & $377.5 \mathrm{def}$ & $14.95 \mathrm{f}-1$ & $16.60 \mathrm{e}$ & $35.28 \mathrm{cde}$ & $49.75 \mathrm{a}$ \\
Seval & $373.3 \mathrm{ab}$ & $376.3 \mathrm{def}$ & $15.23 \mathrm{e}-\mathrm{h}$ & $16.93 \mathrm{de}$ & $33.33 \mathrm{de}$ & $40.13 \mathrm{e}$ \\
Müfitbey & $345.0 \mathrm{abc}$ & $372.5 \mathrm{def}$ & $18.28 \mathrm{~b}$ & $19.75 \mathrm{a}$ & $35.23 \mathrm{cde}$ & $46.05 \mathrm{bc}$ \\
\hline Ortalama & 321.9 & 407.5 & 16.19 & 17.77 & 34.01 & 41.00 \\
F (Çeşitler) & $2.57 * *$ & $7.58 * *$ & $32.16 * *$ & $69.05 * *$ & $13.72 * *$ & $52.18 * *$ \\
V.K. (\%) & 15.1 & 10.0 & 4.1 & 2.0 & 8.6 & 4.1 \\
\hline
\end{tabular}


Çizelge 3. Ekmeklik buğday çeşitlerinde başakta tane verimi, birim alan tane verimi, bin tane ağırlığına ait ortalamaların farklılık gruplandırmaları ve bazı istatistiksel değerleri.

Table 3. The grouping according to mean difference and some statistical values of grain weight per spike, grain yield and 1000 kernel weight on the bread wheat varieties.

\begin{tabular}{|c|c|c|c|c|c|c|}
\hline \multirow{2}{*}{ Çeşitler } & \multicolumn{2}{|c|}{ Başakta Tane Verimi (g) } & \multicolumn{2}{|c|}{ Birim Alan Tane Verimi $\left(\mathrm{kg} \mathrm{da}^{-1}\right)$} & \multicolumn{2}{|c|}{ Bin Tane Ağırlığı (g) } \\
\hline & 2008 & 2009 & 2008 & 2009 & 2008 & 2009 \\
\hline Köse 220/39 & 0.8181 & $1.090 \mathrm{~g}$ & $146.3 \mathrm{~b}-\mathrm{e}$ & $219.2 \mathrm{~h}$ & $29.33 \mathrm{c}-\mathrm{f}$ & $35.41 \mathrm{~h}$ \\
\hline Bezostaja 1 & $1.394 \mathrm{bc}$ & $1.763 \mathrm{~d}$ & $169.7 \mathrm{abc}$ & $265.0 \mathrm{~g}$ & $33.57 \mathrm{a}$ & $39.56 \mathrm{de}$ \\
\hline Kıraç 66 & $0.827 \mathrm{~h}_{1}$ & $1.270 \mathrm{f}$ & 156.3 a-e & $275.8 \mathrm{fg}$ & $30.45 \mathrm{bc}$ & 33.361 \\
\hline Gerek 79 & $1.043 \mathrm{e}-\mathrm{h}$ & $1.491 \mathrm{e}$ & $192.2 \mathrm{a}$ & 344.6 cde & $29.11 \mathrm{def}$ & $35.57 \mathrm{~h}$ \\
\hline Gün 91 & $1.220 \mathrm{cde}$ & $1.774 \mathrm{~d}$ & $127.5 \mathrm{e}$ & $361.9 \mathrm{~b}-\mathrm{e}$ & 28.70 ef & $37.49 \mathrm{~g}$ \\
\hline Kırgiz 95 & $1.161 \mathrm{def}$ & $1.816 \mathrm{~cd}$ & $188.2 \mathrm{a}$ & $385.6 \mathrm{abc}$ & $33.12 \mathrm{a}$ & $41.08 \mathrm{~cd}$ \\
\hline İkizce 96 & $0.970 \mathrm{fgh}$ & $1.609 \mathrm{e}$ & $176.3 \mathrm{abc}$ & $318.6 \mathrm{ef}$ & $28.08 \mathrm{f}$ & $34.80 \mathrm{~h}$ \\
\hline Aytın 98 & $0.923 \mathrm{gh} 1$ & $1.561 \mathrm{e}$ & $139.4 \mathrm{cde}$ & $335.4 \mathrm{de}$ & $29.99 \mathrm{bcd}$ & $39.15 \mathrm{ef}$ \\
\hline Harmankaya 99 & $1.492 \mathrm{ab}$ & $2.223 \mathrm{a}$ & $177.9 \mathrm{ab}$ & $389.4 \mathrm{abc}$ & $33.67 \mathrm{a}$ & $43.65 \mathrm{~b}$ \\
\hline Karahan 99 & $1.126 \mathrm{~d}-\mathrm{g}$ & $1.539 \mathrm{e}$ & $150.0 \mathrm{~b}-\mathrm{e}$ & $330.6 \mathrm{de}$ & $33.54 \mathrm{a}$ & $38.64 \mathrm{ef}$ \\
\hline Altay 2000 & $1.127 \mathrm{~d}-\mathrm{g}$ & $1.966 \mathrm{~b}$ & $131.9 \mathrm{de}$ & $347.5 \mathrm{cde}$ & $28.68 \mathrm{ef}$ & $39.51 \mathrm{de}$ \\
\hline Demir 2000 & $1.626 \mathrm{a}$ & $2.192 \mathrm{a}$ & $149.1 \mathrm{~b}-\mathrm{e}$ & $377.5 \mathrm{a}-\mathrm{d}$ & $34.12 \mathrm{a}$ & $42.32 \mathrm{bc}$ \\
\hline Bayraktar 2000 & $1.195 \mathrm{c}-\mathrm{f}$ & $1.595 \mathrm{e}$ & $177.2 \mathrm{ab}$ & $420.2 \mathrm{a}$ & $34.07 \mathrm{a}$ & $39.46 \mathrm{e}$ \\
\hline Sönmez 2001 & $1.392 \mathrm{bc}$ & $1.966 \mathrm{~b}$ & $175.0 \mathrm{abc}$ & 346.9 cde & $33.37 \mathrm{a}$ & $39.56 \mathrm{de}$ \\
\hline Tosunbey & $1.120 \mathrm{~d}-\mathrm{g}$ & $1.928 \mathrm{bc}$ & 164.1 a-e & $391.3 \mathrm{abc}$ & $28.66 \mathrm{ef}$ & $37.67 \mathrm{fg}$ \\
\hline Seval & $1.071 \mathrm{efg}$ & $1.749 \mathrm{~d}$ & $167.5 \mathrm{a}-\mathrm{d}$ & $358.6 \mathrm{~b}-\mathrm{e}$ & 29.79 cde & 39.92 de \\
\hline Müfitbey & $1.330 \mathrm{bcd}$ & $2.253 \mathrm{a}$ & $148.5 \mathrm{~b}-\mathrm{e}$ & $404.2 \mathrm{ab}$ & $31.06 \mathrm{~b}$ & $45.23 \mathrm{a}$ \\
\hline Ortalama & 1.167 & 1.752 & 161.0 & 345.4 & 31.13 & 38.96 \\
\hline F (Çeşitler) & $10.40 * *$ & $47.72 * *$ & $3.03 * *$ & $12.29 * *$ & $33.28 * *$ & $38.75 * *$ \\
\hline V.K. (\%) & 12.0 & 5.3 & 13.7 & 8.7 & 2.5 & 2.6 \\
\hline
\end{tabular}

Metrekarede başak sayısında genotipin etkisi yanında kuraklık stresinin etkisi de önemlidir (Simane ve ark. 1993). Verim unsurları içerisinde metrekarede başak sayısı, tane verimine doğrudan etkisi nedeniyle birinci seviyede önemlidir (Sönmez ve ark. 1999). Birim alandan alınan tane veriminin arttırılmasında yüksek metrekarede fertil başak sayısına sahip olan genotipler önem kazanmaktadır (Öztürk ve Akten 1999). Naneli ve ark. (2015) kış aylarındaki yağıştaki düşüşün kardeşlenmeyi olumsuz etkilediğini, bahar aylarındaki düşük yağışın başak oluşum ve gelişimini olumsuz etkileyebileceğini belirtmişlerdir. Kaydan ve Yağmur (2008)'un 16 ekmeklik buğday çeşidi ile Van koşullarında yaptığı araştırmada metrekarede fertil başak sayısı ortalamalarını 265.3-412.3 başak $\mathrm{m}^{-2}$, Dönmez (2002)'in Haymana'da 25 ekmelik buğday genotipi ile yaptığı araştırmada metrekarede fertil başak sayısı ortalamalarını 242.8-597.5 başak $\mathrm{m}^{-2}$ olarak gözlemlediği araştırma ile bulgularımız benzerlik taşımaktadır. Çağlar ve ark. (2006)'nın ekmeklik buğdayda metrekardede fertil başak sayısı ortalamalarını 373.8-604.4 başak $\mathrm{m}^{-2}$ gözlemlemiş ve Demir 2000 'in en düşük metrekarde başak sayısına sahip çeşitlerden biri olduğunu vurguladıkları çalışma ile elde ettiğimiz veriler uyumludur.

\subsection{Başakta fertil başakçık sayısı}

Başakta fertil başakçık sayısı yönünden ilk y1l deneme sonuçları incelendiğinde; 20.03 adet ile en yüksek değer Demir 2000'nden elde edilirken, en düşük değeri 13.85 fertil başakçı/kaşak ile Aytın 98 göstermiştir. Diğer çeşitler bu iki değer arasında yer almıştır. İkinci deneme yılında Gün 91 çeşidi 20.20 fertil başakçık/başak sayısı ile en yüksek değeri alırken, bunu Demir 2000 çeşidi 19.95 fertil başakçı/başak ile izlemiş̧ir. Yine ilk yıl olduğu gibi Aytın 98 çeşidi ikinci yılda en düşük başakta fertil başakçık sayısını gösteren çeşit olmuştur. Başakta fertil başakçık sayısı ortalamaları bakımından çeşitler istatistiksel olarak \% 5 önemlilik seviyesinde ilk y1l 10 , ikinci yıl ise 6 farklı grupta yer almıştır.

İlk deneme yılında Gün 91 çeşidinin başaklarının uç kısımlarında steril başakçık oluşumları gözlemlenmiştir. Bezostaja I çeşidinde ise ekstra başakçık oluşumları görülmüştür. Genotiplerin fazladan başakçık oluşturma eğilimleri farklı olup, çeşit teşhisinde kullanılabilmektedir (Hervey-Murray 1980). Başakta fertil başakçık sayısı başakta tane sayısına doğrudan etkisi nedeniyle önemlidir. Başakta fertil başakçık sayısının genotipe ve çevreye (Kün 1996), birim alandaki fertil başak sayısına (Demir 1982), ana sap ve kardeşler ile ekim sıklığına (Geçit 1982) bağlı olduğu belirtilmektedir.

\subsection{Başakta tane saylst}

Başakta tane sayısı ortalamaları birinci yıl 34.01 tane/başak, ikinci y1l ise 41.00 tane/başak olarak belirlenmiştir. Birinci deneme yllında; Demir 2000 çeşidi 43.75 tane/başak ile en yüksek başakta tane sayısı ortalamasını göstermiş, bu çeşidi 42.25 tane/başak ortalama ile Harmankaya 99 çeşidi takip etmiştir. Başakta tane sayısı ortalamalarında en düşük değer ise Köse 220/39 çeşidinden (22.58 tane/başak) elde edilmiştir. İkinci deneme yılında; en yüksek başakta tane sayısı ortalamalarını Harmankaya 99 (50.43 tane/başak) ve Tosunbey (49.75 tane/başak) çeşitleri vermiştir. İlk yetiştirme döneminde olduğu gibi ikinci yılda da en düşük başakta tane sayısı ortalamasını yine Köse 220/39 (26.18 tane/başak) çeşidi göstermiştir.

Olumsuz çevre şartları, başaktaki başakçık ve başakçıktaki çiçek sayısında azalmaya veya tozlanmış çiçeklerin ölümü nedeniyle başaktaki tane sayısında kayıplara neden olabilmektedir. Birim alan tane veriminin yükseltilmesi için başakta tane sayısı fazla genotiplere ve başakta tane sayısını arttırıcı tarımsal uygulamalara önem verilmelidir (Öztürk ve 
Akten 1999). Kaydan ve Yağmur (2008), Kınacı ve ark. (2008), Dönmez (2002) ve Aydoğan ve Soylu (2017)'nun araştırmalarında elde ettiği sonuçlar ile bulgularımız benzerlik içerisindedir.

\subsection{Başakta tane verimi}

Birinci yetiştirme döneminde başakta tane verimine ait ortalama $1.167 \mathrm{~g}$, ikinci yetiştirme döneminde ise $1.752 \mathrm{~g}$ olarak gerçekleşmiştir. İlk yıl Demir $20001.626 \mathrm{~g}$ ile, ikinci yıl ise $2.253 \mathrm{~g}$ ile Müfitbey çeşidi en yüksek başakta tane verimi ortalamasını vermiştir. Her iki deneme yılında da Köse 220/39 çeşidi en düşük ortalama değere sahip çeşit olmuştur. Başakta tane verimi ortalamaları istatistiki olarak \%5 önemlilik düzeyinde ilk yıl 9, ikinci yılda ise 7 farklı grupta yer almıştır.

Buğdayda tane verimini arttırmak için, başakta tane sayısı yanında başakta tane ağırlığının da arttırılması gerekmektedir. Verimi doğrudan etkileyen ana öğelerden biri de başakta tane ağırlığıdır (Kahraman 2006). Başakta tane verimi ana sap ve kardeşlere (Geçit ve ark. 1987), genotipe ve çevreye (Çölkesen ve ark. 1999), başak boyu ile başaktaki tane sayısına (Akdamar ve ark. 2002), ekim zamanına (Kahraman 2006), ekim sıklı̆̆ına (Geçit 1982) göre değişmektedir. Kahraman (2006), Kınacı ve ark. (2008)'nın çalışmalarında elde ettikleri bulgularla sonuçlarımız uyumludur.

\subsection{Birim alan tane verimi}

Birim alan tane verimi yönünden 2007-2008 yetiştirme döneminde çeşitler ortalaması $161.0 \mathrm{~kg} \mathrm{da}^{-1}$ iken 2008-2009 döneminde $345.4 \mathrm{~kg} \mathrm{da}^{-1}$ olarak gerçekleşmiştir. Birinci yıl Gerek $79192.2 \mathrm{~kg} \mathrm{da}^{-1}$ verimi ile ilk sırada yer alırken 127.5 $\mathrm{kg} \mathrm{da}^{-1}$ ile Gün 91 çeşidi son sırada yer almıştır. İkinci yıl Bayraktar $2000420.2 \mathrm{~kg} \mathrm{da}^{-1}$ ile en yüksek birim alan tane verimini verirken Köse $220 / 39$ çeşidi $219.2 \mathrm{~kg} \mathrm{da}^{-1}$ ile en düşük değeri göstermiştir. Birim alan tane veriminde; az yağışlı geçen ilk yılda istatistiki olarak \% 5 önemlilik seviyesinde 5 , yağ 1 şl geçen ikinci deneme y1lında ise ortalamalar 8 farklı grupta toplanmıştır. Daha yağışlı geçen ikinci yılda Köse 220/39 çeşidinde yatma görülmüştür. Birinci yetiştirme döneminde Gün 91'de ise özellikle başakların uç kısmında sterilite gözlenmiştir. Gün 91 çeşidi ilk deneme yılına göre ikinci yıl birim alan tane verimini en çok arttıran çeşitlerden biri olmuştur.

Birim alan tane verimi genotip, çevre ve kültürel işlemlerinin etkisi altındadır. İki deneme yılının iklim verileri incelendiğinde özellikle yağış ve sıcaklık yönünden uzun yıllar ortalamalarından büyük sapmalar gösterdiği görülmektedir. İkinci deneme yılında tüm verim unsurları ilk yıla göre artış göstermiştir. Birim alan tane veriminde de yaklaşık iki katlık bir artış görülmüştür. Birim alan tane verimine ait elde ettiğimiz bulgular Dönmez (2002) ve Aydoğan ve ark. (2007)'nin bulgularıyla uyum içerisindedir.

\subsection{Bin tane ăgırliğl}

Bin tane ağırlığı bakımından birinci deneme yılında $34.12 \mathrm{~g}$ ile Demir 2000 çeşidi ilk sırada yer alırken, İkizce 96 çeşidi $28.08 \mathrm{~g}$ ile son sırada yer almıştır. İkinci deneme yılında en yüksek bin tane ağırlığını $45.23 \mathrm{~g}$ ortalama değeri ile Müfitbey, en düşük değer ise $33.36 \mathrm{~g}$ ile Kıraç 66 çeşidinden elde edilmiştir. İlk yetiştirme döneminde çeşitlerin ortalaması 31.13 $\mathrm{g}$, ikinci yetiştirme döneminde ise $38.96 \mathrm{~g}$ olarak belirlenmiştir. İkinci deneme yılında ilk yıla göre bin tane ağırlığını en fazla arttıran çeşit Müfitbey olmuştur. Altay 2000 ve Seval çeşitleri bu artışta Müfitbey'i takip etmiştir.

Bin tane ağırlığı; genotipe (Genç ve ark. 1993), $\mathrm{m}^{2}$ 'de fertil başak sayısı ve başakta tane sayısına (Öztürk ve Akten 1999), ekolojik koşullara (Kün 1996) bağlı olarak değişmektedir. Bitkinin ana sapına ve kardeşlerine ait başaklarında bin tane ağırlıkları farklılık göstermektedir (Geçit 1982). Gübreleme ve sulama da bin tane ağırlığına etki eden unsurlardandır (Acer 2004).

\subsection{Tarımsal özellikler arasındaki ilişkiler}

$\mathrm{Bu}$ araştırmada incelenen özellikler arasındaki ilişkiler Çizelge 4'de verilmiştir. Metrekarede fertil başak sayısı ile birim alan tane verimi arasında $\left(0.5740^{* *}\right)$, başakta tane verimi $\left(0.2243^{* *}\right)$ ve bin tane ağırlığ $\left(0.3581^{* *}\right)$ arasında pozitif ve önemli ilişki bulunmuştur.

Başakta fertil başakçık sayısı ile başakta tane sayısı $\left(0.7386^{* *}\right)$, başakta tane verimi $\left(0.6884^{* *}\right)$, birim alan tane verimi $\left(0.3854^{* *}\right)$, bin tane ağırlığ $\left(0.4835^{* *}\right)$ arasında pozitif ve önemli ilişki belirlenmiştir. Başakta tane sayısı ile başakta tane verimi $(0.9133 * *)$, birim alan tane verimi $(0.6091 * *)$, bin tane ağırlığ $\left(0.6431^{* *}\right)$ arasında pozitif ve önemli ilişkiler saptanmıştır. Başakta tane verimi ile birim alan tane verimi arasında $\left(0.7791^{* *}\right)$ pozitif ve önemli ilişki bulunmuştur.

Uzun yıllar ortalaması esas alındığında; ilk deneme yılının kurak geçmesi, buna karşın ikinci deneme yılının ise yağışlı geçmesi incelenen özelliklerde sapmalar göstermiştir. Her iki deneme yılının birbirinden çok farklı olması birim alan tane verimi ve diğer özellikler bakımından çeşitlerin potansiyellerinin belirlenmesi bakımından olumlu bir durum olarak görülmüştür. Verim ve verim öğeleri arasındaki ilişkiler, daha önce yapılmış pek çok araştırma ile benzerlik göstermektedir (Öztürk ve Akten 1999; Soylu ve ark. 1999; Yağmur ve Kaydan 2008; Aydoğan ve Soylu 2017). Verim ve verime etki eden unsurların etki dereceleri yıllara göre değişmekte olup bunlar arasında en önemli neden ise iklim koşulları olmaktadır (Kırtok ve Çölkesen 1985).

Çizelge 4. Tarımsal özellikler arasındaki ilişkiler.

Table 4. The relationship between the agronomic traits.

\begin{tabular}{|c|c|c|c|c|c|c|}
\hline & 1 & 2 & 3 & 4 & 5 & 6 \\
\hline 1. Metrekarede Fertil Başak Sayısı & 1.0000 & & & & & \\
\hline 2. Başakta Fertil Başakçık Sayısı & -0.0137 & 1.0000 & & & & \\
\hline 3. Başakta Tane Sayısı & 0.0787 & $0.7386^{* *}$ & 1.0000 & & & \\
\hline 4. Başakta Tane Verimi & $0.2243 * *$ & $0.6884 * *$ & $0.9133 * *$ & 1.0000 & & \\
\hline 5. Birim Alan Tane Verimi & $0.5740 * *$ & $0.3854 * *$ & $0.6091 * *$ & $0.7791 * *$ & 1.0000 & \\
\hline 6. Bin Tane Ağırlı̆̆ & $0.3581 * *$ & $0.4835^{* *}$ & $0.6431 * *$ & $0.8606 * *$ & $0.3820 * *$ & 1.0000 \\
\hline
\end{tabular}

**0.01 düzeyinde önemli

$* *$ Significant at $\mathrm{p}<0.01$ 


\subsection{Glutenin bant deseni}

$\mathrm{Bu}$ çalışmada kullanılan ekmeklik buğday çeşitlerinin Glutenin bantları Çizelge 5'de verilmiştir. Glu-A1 lokusunda, Harmankaya 99 ve Altay 2000 çeşitlerinde bant gözlenmemiştir. Tosunbey, Seval, Sönmez 2001 ve İkizce 96'da 1, diğer çeşitlerde $2 *$ bandı belirlenmiştir. Glu-B1 lokusunda; incelenen çeşitlerin $10^{\prime} \mathrm{u} 7+8$, diğer çeşitler ise $7,7+9$ ve $17+18$ bantlarına sahiptir. Glu-D1'de çeşitler ağırlıklı olarak 5+10 bantlarına sahip olup, 6 çeşit ise $2+12$ bantlarını taşımaktadır.

Çizelge 5. Ekmeklik buğday çeşitlerinin glutenin bantları.

Table 5. Glutenin band patterns of bread wheat varieties.

\begin{tabular}{lccc}
\hline Çeşitler & Glu A1 & Glu B1 & Glu D1 \\
\hline Köse 220/39 & $2^{*}$ & $7+8$ & $2+12$ \\
Bezostaja 1 & $2^{*}$ & $7+9$ & $5+10$ \\
Kıraç 66 & $2 *$ & $7+8$ & $5+10$ \\
Gerek 79 & $2 *$ & $7+8$ & $2+12$ \\
Gün-91 & $2 *$ & $17+18$ & $5+10$ \\
Kırgiz-95 & $2^{*}$ & $7+8$ & $2+12$ \\
İkizce 96 & 1 & $7+9$ & $5+10$ \\
Aytın 98 & $2 *$ & $7+8$ & $2+12$ \\
Harmankaya-99 & Bant yok & $7+8$ & $5+10$ \\
Karahan-99 & $2 *$ & $7+8$ & $5+10$ \\
Altay 2000 & Bant yok & $17+18$ & $5+10$ \\
Demir 2000 & $2 *$ & $7+9$ & $2+12$ \\
Bayraktar 2000 & $2 *$ & $7+8$ & $5+10$ \\
Sönmez 2001 & 1 & 7 & $2+12$ \\
Tosunbey & 1 & $17+18$ & $5+10$ \\
Seval & 1 & $7+8$ & $5+10$ \\
Müfitbey & $2 *$ & $7+8$ & $5+10$ \\
\hline & & &
\end{tabular}

Gluten, albumin ve globulin ekmeklik buğdayın proteinini oluşturmaktadır. Gluten de çözünme durumlarına göre iki alt protein olan glutenin ve gliadine ayrılmakta olup bunlar çevre faktörlerinden etkilenmemekte dolayısıyla genotiplere özgüdürler. Gliadinlere göre daha yüksek molekül ağırlığına sahip olan gluteninlerin ekmeklik buğdayın kalitesi ile ilişkisi üzerine pek çok araştırma yapılmıştır (Payne ve ark. 1987; Graybosch 1992; Lookhart ve ark. 1993; Wang ve Ning 1995; Galova ve ark. 2003; Y1ldiz ve ark. 2014).

Yeni geliştirilen çeşitlerin tescil edilmesinde veya 1slahçı hakları kapsamında koruma altına alınmasında farklılık, yeknesaklık ve durulmuşluk (FYD) testleri yapılmaktadır. Uluslararası Yeni Bitki Çeşitlerini Koruma Birliği (UPOV) tarafından çeşit ayrım kriteri olarak 27 karaktere ilave olarak glutenin bant desenlerini içeren 3 ilave karakter bulunmaktadır (UPOV 2017). Bu araştırmada, glutenin bant desenlerinin belirlenerek çeşitlerin tanımlanması amaçlanmıştır. Bu nedenle kalite kriterleri ile glutenin bantları arasındaki ilişkiler incelenmemiştir. Gerek yüksek molekül ağırlıklı gluteninler gerekse de düşük molekül ağırlığına sahip gluteninler morfolojik tanımlama yapıldıktan sonra genotipik tanımlama yapmak için genetik saflığın korunmasında ve doğrulanmasında büyük fayda sağlamaktadır.

\subsection{Gliadin bant deseni}

$\mathrm{Bu}$ çalışmada materyal olarak kullanılan ekmeklik buğday çeşitlerinin gliadin bantları, nispi hareketlilikleri ve nispi yoğunluklarına göre Şekil 1'de gösterilmiştir. Her siyah kutucuk bir gliadin bandını sembolize etmekte ve kutucukların içerisinde de rakamlarla 1-5 skalası (1-En az boyanan 5-En fazla boyanan) esas alınarak bantların nispi yoğunlukları verilmiştir. Gliadin bant desenleri yönünden yüksek oranda farklı tipleri içeren çeşitlerin ağırlıklı olan bant desenleri verilmiştir. Az sayıda tip dışı bitkiler içeren çeşitlerde bu durum göz ardı edilerek ağırlıklı bant desenine göre okumalar yapılmıştır. Fazla miktarda farklı tiplerden oluşan çeşitlerde (Köse 220/39 ve Gerek 79) baskın olan iki tipte okumalar yapılarak verilmiştir.

Ülkemizde bitki çeşitlerinin tescil işlemlerini yürüten Tohumluk Tescil ve Sertifikasyon Merkez Müdürlüğü'nde gliadin analizleri morfolojik gözlemleri destekleyici unsur olarak etkin bir şekilde kullanılmaktadır. Çevresel faktörlerin gliadinleri etkilememesi ve az bir numunenin analiz için yeterli olması ile hızlı bir yöntem olması çeşit teşhisinde avantajlar sağlamaktadır (Bushuk ve Zillman 1978; Yupsanis 1983; Lookhart ve ark. 2005). Bu çalışmadan elde edilen bulgular Dönmez (2009) ile benzerlik göstermiştir.

\section{Sonuç}

Çalışmamızda, Orta Anadolu Bölgesinde kuru koşullarda yetiştirilen ekmeklik buğday çeşitlerinin aynı çevre koşullarında verim ve verim unsurları belirlenmiştir. $\mathrm{Bu}$ araştırmanın yapıldığı 2007-2008 ile 2008-2009 yetiştirme dönemlerinde yağış, yağışın yıl içerisindeki dağılımı ve sıcaklık yönünden birbirinden oldukça farklı iki yıl yaşanmıştır. İklim koşulları açısından farklı iki yıl yaşanması, çeşitlerin potansiyellerini ortaya koyma açısından olumlu karşılanmıştır. İlk yetiştirme y1lında birim alan tane veriminde Gerek 79 en yüksek değeri gösterirken 9 çeşit ile aynı istatistiksel grupta yer almıştır. İkinci y1l ise Bayraktar 2000 çeşidi en yüksek birim alan tane verimini vermiş ve 5 çeşit ile aynı istatistiksel gruba girmiştir. Bayraktar 2000 çeşidi; kurak geçen ilk yıl Gerek 79 çeşidi ile aynı istatistiksel gurupta yer almış, ikinci yıl yağış miktarındaki artışa daha iyi tepki vererek verimini Gerek 79'dan daha fazla arttırmıştır.

$\mathrm{Bu}$ araştırmada incelenen çeşitlerin ağırlıklı olarak; Glu A1 lokusunda 2*, Glu B1 lokusunda 7+8, Glu D1 lokusunda ise $5+10$ bantlarını taşıdığı belirlenmiştir. Ayrıca gliadin bant desenleri yönünden de çeşitlerin tanımlanması yapılmıştır. Bitki morfolojisine dayalı çeşit ayrım kriterleri yanında, glutenin ve gliadin bant desenleri de çeşit muhafazasında etkin bir şekilde destekleyici bir unsur olarak kullanılabilir. 


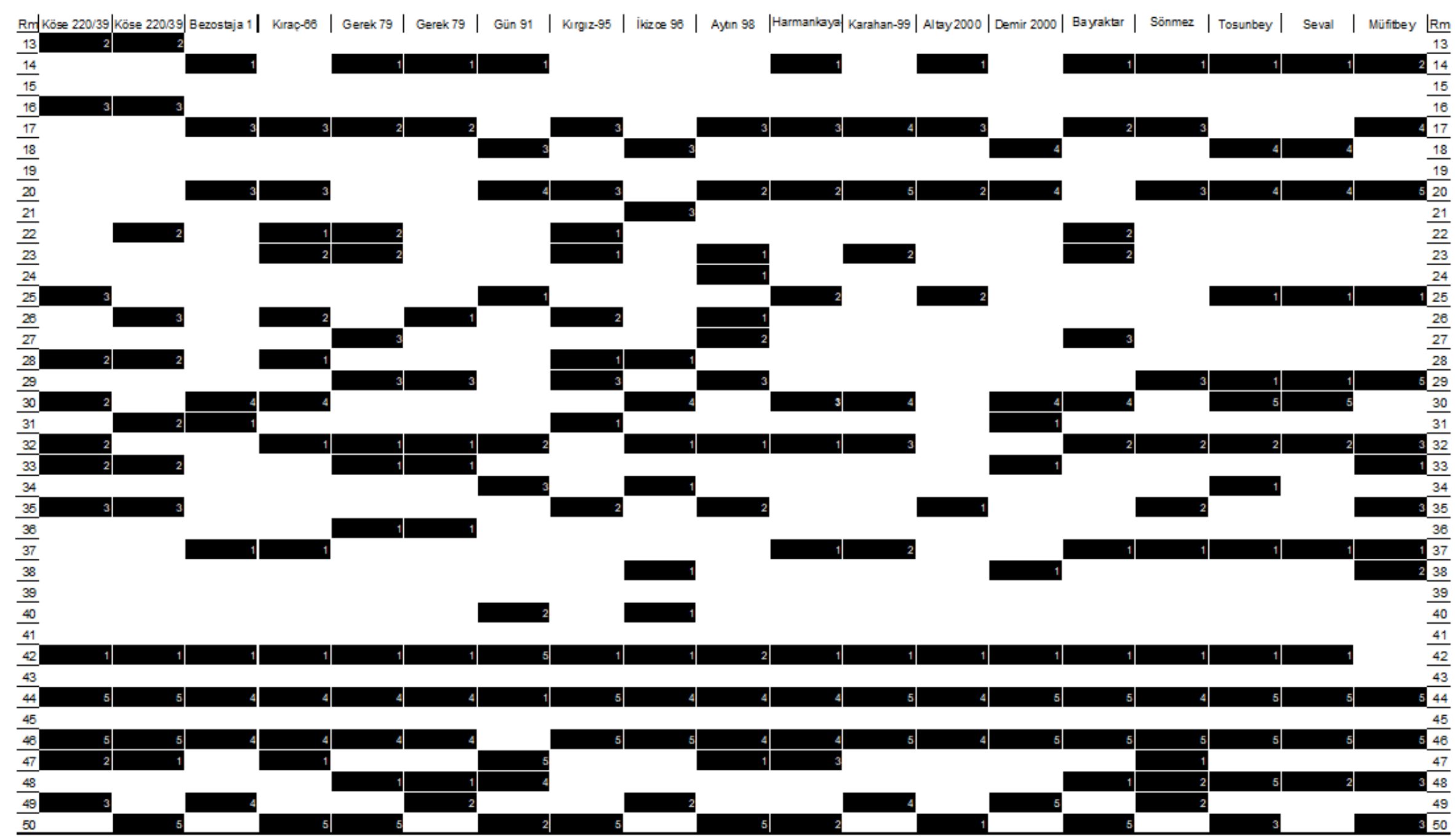

Şekil 1. Ekmeklik buğday çeşitlerinin gliadin bantları.

Figure 1. Gliadin bant patterns of some bread wheat varieties. 


\section{Kaynaklar}

Acer S (2004) Bazı makarnalık buğday çeşitlerinin verim ve kalite özellikleri üzerine farklı sulama zamanları ile azot dozlarının etkisi. Doktora tezi, Ankara Üniversitesi Fen Bilimleri Enstitüsü, Ankara.

Akdamar M, Tayyar Ş, Gökkuş A (2002) Effects of different sowing times on yield and yield related traits in bread wheat grown in Çanakkale. Akdeniz Üniversitesi Ziraat Fakültesi Dergisi 15(2): 8187.

Akkaya A (1994) Buğday Yetiştiriciliği. Sütçü İmam Üniversitesi Ziraat Fakültesi Genel Yayın No: 1, Ders Kitapları Yayın No: 1, Kahramanmaraş.

Aydoğan S, Akçacık AG, Şahin M, Kaya Y (2007) Ekmeklik buğday (T. aestivum L.) genotiplerinde verim ve bazı kalite özellikleri arasındaki ilişkiler. Tarla Bitkileri Merkez Araştırma Enstitüsü Dergisi 16(1-2): 21-30.

Aydoğan S, Soylu S (2017) Ekmeklik Buğday Çeşitlerinin Verim ve Verim Öğeleri ile Bazı Kalite Özelliklerinin Belirlenmesi. Tarla Bitkileri Merkez Araştırma Enstitüsü Dergisi 2017, 26(1): 24-30.

Bushuk W, Zillman RR (1978) Wheat Cultivar Identification by Gliadin Electrophoregrams. I. Apparatus, Method and Nomenclature. Can. J. Plant Sci. 58: 505.

Çağlar Ö, Öztürk A, Bulut S (2006) Bazı ekmeklik buğday çeşitlerinin Erzurum Ovası koşullarına adaptasyonu. Atatürk Üniv. Ziraat Fak. Derg. 37(1): 1-7.

Çölkesen M, Cesurer L, Yürürdurmaz C, Demirbağ V, Çiçek A, Başgül A, Engin A (1999) Kahramanmaraş Koşullarına Uygun Yüksek Verimli Arpa Çeşitlerinin Belirlenmesi. Türkiye III. Tarla Bitkileri Kongresi, 15-18 Kasım, Adana, 234-239.

Demir Z (1982) Kışlık arpada tohum irilik, miktar ve sıra arası açıklığının tane verimine etkileri. Doktora tezi, Ankara Üniv., Ankara, s. 52.

Dönmez E (2002) Bazı ekmeklik buğday (Triticum aestivum L.) çeşitlerinde genotip x çevre interaksiyonları ve stabilite analizleri üzerine bir araştırma. Gaziosmanpaşa Üniversitesi Fen Bilimleri Ens., Doktora tezi, Tokat.

Dönmez Ö (2009) Türkiye'de tescil edilmiş bazı ekmeklik buğday çeşitlerinin glutenin ve gliadin bant desenleri. Tohumluk Tescil ve Sertifikasyon Merkez Müdürlüğü, Ankara.

Galova Z, Starovicova M, Knoblochova H, Greganova Z (2003) Biochemical and molecular characterization of new wheat genotypes. Section Cellular and Molecular Biology v. 58(6) pp. 1061-1066.

Geçit HH (1982) Ekmeklik buğday (Triticum aestivum L.em Thell) çeşitlerinde ekim sıklıklarına göre birim alan değerleri ile ana sap ve çeşitli kademedeki kardeşlerin tane verimi ve verim komponentleri üzerine araştırmalar. Doçentlik tezi, Ankara Üniversitesi, Ankara.

Geçit HH, Gürbüz B, Özcan S (1987) Ekmeklik buğdayda ekim sıklığının birim alan değerleri üzerine etkileri. Türkiye Tahıl Sempozyumu, 8-9 Ekim 1987, Bursa, s. 159-170.

Genç İ, Yağbasanlar T, Özkan H (1993) Akdeniz iklim kuşağına uygun makarnalık buğday çeşitlerinin belirlenmesi üzerinde araştırmalar. Makarnalık Buğday Mamülleri Sempozyumu, 30 Kasım-3 Aralık, s. 127-141, Ankara.

Graybosch RA (1992) High molecular weight glutenin subunit composition of cultivars, germplasm, and parents of U.S. red winter wheat. Crop science (USA) v. 32(5) pp. 1151-1155.

Hervey-Murray CG (1980) The identification of cereal varieties. RHM Arable Services Limited, Cambridge.

Kahraman T (2006) Bazı ekmeklik buğday çeşitlerinde farklı ekim zamanı ve azotlu gübreleme uygulamalarının, tane dolum süresi ve tane dolum oranı ile verim ve kalite unsurlarına etkilerinin belirlenmesi. Trakya Üniversitesi Fen Bilimleri Enstitüsü, Doktora tezi, Tekirdağ.
Kaydan D, Yağmur M (2008) Van ekolojik koşullarında bazı ekmeklik buğday (Triticum aestivum L.) çeşitlerinin verim ve verim öğeleri üzerine bir araștırma. Ankara Üniversitesi Ziraat Fakültesi Tarım Bilimleri Dergisi 14(4): 350-358.

Khan K, Hamada AS, Jocobsen A, Huckle L (1990) Procedure for Wheat Cultivar Identification by Polyacrylamide Gel Electrophoresis (Page) of Gliadin Proteins. Department of Cereal Science and Food Technology, Nort Dakota State University, Fargo, Nort Dakota.

Kınacı G, Budak Z, Kutlu İ, Tarhan P, Tavas N, Gıcı BN, Gündüz F, Bozkuş C, Kınacı E (2008) Değişik olgunlaşma süreli buğday çeşitlerinin Eskişehir koşullarına adaptasyonu üzerine bir araştırma. Ülkesel Tahıl Sempozyumu, 2-5 Haziran 2008, Konya, s. 93-100.

Kırtok Y, Çölkesen M (1985) Çukurova Koşullarında Denemeye Alınan Arpa Çeşitlerinde Önemli Bazı Verim Unsurları Üzerinde Path Katsayısı Analizi. Doğa Bilim Dergisi, Seri: D2, Cilt: 9, Sayı: 1.

Kün E (1988) Serin iklim tahılları. Ankara Üniversitesi Ziraat Fakültesi Yayınları, No:1032 Ders Kitabı, 299, Ankara, s. 322.

Kün E (1996) Tahıllar-I (Serin İklim Tahılları). Ankara Üniversitesi Ziraat Fakültesi Yayınları, Yayın No: 1451, Ders kitabı 431, Ankara.

Lookhart GL, Hagman K, Kasarda DD (1993) High-molecular-weight glutenin subunits of the most commonly grown wheat cultivars in the U.S. in 1984. Plant Breeding (Germany) v. 110(1) pp. 48-62.

Lookhart GL, Bean SR, Culbertson C (2005) Wheat quality and wheat varietal identification. Proceedings of the 12th International ICC Cereal and Bread Congress, Harrogate, UK, 23-26th May 2004. pp. 293-297.

MGM (2009) İklim verileri. Meteoroloji Genel Müdürlüğü, Ankara.

Naneli İ, Sakin MA, Kıral AS (2015) Tokat-Kazova Şartlarında Bazı Ekmeklik Buğday (Triticum aestivum L.) Çeşitlerinin Verim ve Kalite Özelliklerinin Belirlenmesi. Gaziosmanpaşa Üniversitesi Ziraat Fakültesi Dergisi, 32(1): 91-103.

Öztürk A, Akten Ş (1999) Kışlık buğdayda bazı morfofizyolojik karakterler ve tane verimine etkileri. Tr. J. of Agriculture and Forestry 23; 409-422.

Payne PI, Mark NA, Anatole KF, Linda HM (1987) The Relationship HMW Glutenin Subunit Composition and the Bread-making Quality of British-grown Wheat Varieties. J. Sci. Food Agric. 40, 51-65.

SAS Institute (1998) SAS/STAT User's guide. Version $7^{\text {th }}$. SAS Institute, Cary, NC.

Simane B, Struik PC, Nachit MM, Peacock JM (1993) Ontogenetic Analysis of Yield Component Yield Stability of Durum Wheat in Water-Limited Enviroments. Euphytica 71: 211-219.

Soylu S, Topal A, Sade B, Akgün N (1999) Konya Şartlarında Bazı Ekmeklik Buğday Çeşitlerinin Verim ve Verim Öğelerinin Belirlenmesi. Selçuk Üniversitesi, Ziraat Fakültesi Dergisi 13(20), Konya, s. 60-73.

Sönmez F, Ülker M, Yılmaz N, Ege H, Bürün B, Apak R (1999) Tir buğdayında tane verimi ile bazı verim öğeleri arasındaki ilişkiler. Tr. J. of Agriculture and Forestry 23: 45-52.

Tosun O, Yurtman N (1973) Ekmeklik buğdaylarda (Triticum aestivum L. Em Thell) verime etkili morfolojik ve fizyolojik özellikler. Ankara Üniversitesi Ziraat Fakültesi Yıllığı 23: 418-434.

TTSMM (2009) Tohumluk Sertifikasyon Faaliyet Raporu. Tohumluk Tescil ve Sertifikasyon Merkez Müdürlügü̈, Ankara.

TTSMM (2016) Tohumluk Sertifikasyon Faaliyet Raporu. Tohumluk Tescil ve Sertifikasyon Merkez Müdürlüğü, Ankara.

TÜİK (2017) www.tuik.gov.tr Erişim 4 Ekim 2017.

UPOV (2017) UPOV-Guidelines For The Conduct Of Tests For Distinctness, Uniformity And Stability. 
Ünver S (1995) Buğdayda tohum iriliğinin verim ve verim öğeleri üzerine etkisi. TARM Yayın No: 1, Ankara, s. 37.

Wang R, Ning K (1995) Correlation of high-molecular-weight glutenin subunit compositions of some elite wheat lines and their hybrid progenies to bread-making quality. Acta Agriculturae BorealiOccidentalis Sinica (China) v. 4(4) pp. 25-30.

Yağmur M, Kaydan D (2008) Kışlık buğdayda tane verimi, verim öğeleri ve fenolojik dönemler arasındaki ilişkiler. Harran Ün. Ziraat Fakültesi Dergisi 12(4): 9-18.
Yıldız A, Akan K, Akçura M (2014) Türkiye'nin Doğu Bölgesinden Toplanan Bazı Yerel Ekmeklik Buğday Popülasyonlarından Seçilen Saf Hatların Yüksek Molekül Ağırlıklı Glutenin Alt Birimlerinin İncelenmesi. Tarım Bilimleri Dergisi 21(2015): 346-354.

Yupsanis T (1983) Identification and technological screening of wheat varieties by electrophoresis of gliadins. Georgiki Erevna (Greece) v. 7(2) pp. 157-167. 